\title{
From Creeping to Full-Blown Crisis: Lessons from the Dutch and Swedish Response to Covid-19
}

Alina Engström, Marte Luesink, and Arjen Boin

\begin{abstract}
On the last day of 2019, China alerted the World Health Organization to a cluster of mysterious pneumonia cases. A new coronavirus (Covid-19) was discovered. Within three months after the alert, Europe had become the epicenter of a global pandemic. Even though the virus spread easily and quickly within communities, it took its time to travel from China to northern Europe. Nevertheless, many governments were slow to respond to the emerging threat. This chapter analyzes the initial phase of the Covid-19 crisis in Sweden and the Netherlands, focusing on the relationship between experts and decision-makers. The chapter discusses four factors that may help explain why the Swedish and Dutch governments were slow in their response. The governments assumed an
\end{abstract}

\section{A. Engström (凶)}

Swedish Institute of International Affairs, Stockholm, Sweden e-mail: alina.engstrom@ui.se

\section{Luesink • A. Boin}

Department of Political Science, Leiden University, Leiden, The Netherlands e-mail: m.b.a.luesink@fsw.leidenuniv.nl; boin@fsw.leidenuniv.nl

(C) The Author(s) 2021

A. Boin et al. (eds.), Understanding the Creeping Crisis, https://doi.org/10.1007/978-3-030-70692-0_7 
epidemic like the one in China would not happen in their country, the experts followed international scientific guidelines, citizens were expected to defy limitations on their freedoms, and both experts and decisionmakers were confident with regard to the level of preparedness. Lessons are formulated for further analysis and future preparations.

Keywords Creeping crisis • Pandemic • Covid-19 • Coronavirus • Infectious diseases

\subsection{Introduction: A Slow Surprise}

On December 31, 2019, China alerted the World Health Organization (WHO) that a cluster of pneumonia cases of unknown origin had emerged in a region of the country. In the months following, what was eventually diagnosed as a coronavirus spread from a seafood market in Wuhan-the first identified source of contagion - to virtually every corner in the world. The virus was deadly and highly contagious; that much was known. But many uncertainties persisted (Buckley \& Myers, 2020).

Covid-19, the disease caused by the corona virus, slowly developed into the biggest crisis since World War II. By mid-January 2020, cases had been reported in several countries surrounding China, including Japan and South Korea. In China, the cases grew exponentially and tough measures were taken by the government. On January 23, Wuhan City, as well as neighboring municipalities, was locked down to contain the spread of the virus (WHO, 2020a). Global media closely watched and reported on the unfolding story. The next day, the first COVID-19 case was reported in France (Spiteri et al., 2020). The virus had reached Europe.

Within days of that first case, coronavirus was reported in multiple European countries. Sweden detected its first case in the city of Jönköping (TT, 2020a). The patient had returned from a trip to China, albeit without symptoms, on January 24,2020 . The case did not come as a surprise for Folkhälsomyndigheten - the Swedish Public Health Agency (FOHM) as it had been monitoring about 20 people who had traveled to the infected areas in China during the previous two weeks (TT, 2020b).

In February 2020, the number of corona cases increased, but there still seemed little reason for alarm. On February 13, the European Centre for Disease Prevention and Control (ECDC) stated that "the risk associated with SARS-CoV-2 infection for the EU/EEA and UK population is 
currently low" (ECDC, 2020, p. 1). On February 20, a corona case was reported in northern Italy. It marked the beginning of a coronavirus "explosion" in Europe. Within three days, the number of corona cases went up to 150 (Lawler, 2020). Northern Italy being a popular holiday destination, many European tourists unknowingly contracted the coronavirus and brought it home with them.

The Netherlands reported its first case on February 27 (NU.nl, 2020). At the end of February, health experts and government officials in both the Netherlands and Sweden reassured their citizens that their respective health systems were well-prepared, and management protocols were in place (NOS, 2020a; Von Hall, 2020). That claim would come undone within a matter of weeks, however. During the first half of March, both countries experienced a sharp and rapid increase in Covid-19 patients requiring hospital care. It was during that period that both countries shifted into crisis mode.

Sweden activated its Crisis Management Council (Krishanteringsrådet), and as the national Public Health Agency (FOHM) raised the risk of domestic spread from "low" to "moderate", a National Pandemic Group was activated (Folkhälsomyndigheten [FOHM], 2020a). Gatherings of more than 500 people were forbidden. Events then unfolded in rapid succession. On March 11, Sweden reported its first death caused by the coronavirus (TT, 2020a). On March 16, the FOHM recommended senior citizens to stay at home and everyone living in the Stockholm region to work from home. On March 17, upper-secondary schools and universities were advised to conduct distance education (primary schools and kindergartens stayed open). On March 19, the FOHM advised against nonessential travel within the country in relation to the upcoming Easter holidays. On March 29, gatherings of more than 50 people were forbidden. On March 31, the government issued a national ban on visits to nursing homes.

The Netherlands also entered a crisis mode during the first week of March 2020. A Ministerial Crisis Team launched and held its first meeting on March 3. The first death related to Covid-19 was reported on March 6 and, on the same day, people living in the province of Noord-Brabant were asked to stay home (Boin, Overdijk, Van der Ham, Hendriks, \& Sloof, 2020). On March 9, the first Covid-19 press conference was held by prime minister Mark Rutte and Jaap van Dissel, head of the Outbreak Management Team (Rijksoverheid, 2020a). A succession of press conferences followed, announcing additional measures including the cancelation 
of large events, the closure of schools, bars and restaurants, and social distancing measures (Rijksoverheid, 2020b, 2020c).

The two countries instituted crisis regimes that would last for months and were, in many respects, quite effective. The curve was flattened, and public support for governments remained high. ${ }^{1}$ The top experts in both countries, Anders Tegnell in Sweden and Jaap van Dissel in the Netherlands, became public figures almost overnight. But while the effectiveness of the crisis regimes has been largely acknowledged in both countries, the timing of the response has become the subject of scrutiny.

The first public criticism in Sweden emerged from an opposition party in Parliament, the center-right Moderate Party, at the end of February. It accused the government of acting too late and doing too little (Lönegård, 2020). By late-March, other opposition parties added to the critique. ${ }^{2}$ The Swedish response was also criticized by some parts of the scientific community (DN-TT, 2020). In the Netherlands, the criticism was initially rather muted, but during the first "corona debate" in Parliament, several opposition parties stated that the government had shown a weak response (Rutten, 2020). The criticism continued to grow and resulted in a widely supported request for a national inquiry (carried out by the Dutch Safety Board).

The case of the coronavirus pandemic in Northern Europe is instructive because it developed over a relatively long period. While shorter than most creeping crises profiled in this book, these developments unfolded over weeks. National officials could "see it coming." Both the Netherlands and Sweden had time to act early, watching Southern Europe absorb the initial impact. Yet the governments of both countries took over six weeks to trigger their respective crisis regimes at a political level. In the interim, health experts played an outsized role when compared to politicians; as such, their assessment of the virus was instrumental in shaping governmental perceptions about the need to act. This chapter takes the unique opportunity presented by Covid-19 to explore the role of health experts

\footnotetext{
${ }^{1}$ In the Netherlands, the approach chosen by the government was supported by $73 \%$ of the population and Rutte's approval rate increased (Kester, 2020). The majority of the political parties agreed with or withheld their critique regarding the chosen approach. The approach was critiqued by only a few and also the experts received little criticism during the early stages of the crisis. In Sweden, the trust in government and the Public Health Agency increased steadily throughout March (Novus, 2020).

${ }^{2}$ The Sweden Democrats criticized the FOHM for not closing schools and the Christian Democrats called for an audit of the government's handling of the pandemic (Oscarsson, 2020).
} 
in declaring this initially creeping crisis, a concept defined in the introduction to this book, as a full-blown crisis.

Our analysis helps to illuminate response patterns to a high-profile, unfolding creeping crisis - with a special emphasis on the expert-politician interface when the actual crisis hits. We seek to explain why both countries arrived at a fairly similar, delayed response. We start this chapter with a brief description of the pandemic management structures in place, focusing on the role and position of national health experts. We then describe the six weeks between the first announcements of the virus and the imposition of the crisis regime. We end with a few lessons to improve recognition of when a creeping crisis may be tipping into a full-blown crisis.

\subsection{Setting the Scene: National Pandemic Management Structures}

\subsubsection{Sweden: Agencies as Crisis Manager}

Sweden has a unique governmental system. The central government is small, while executive power is concentrated in autonomous national agencies and local administrations have substantial powers. Agencies have most of the resources, expertise, and human resources to execute policies (Pierre, 2020, p. 4). Ministerial steering (Ministerstyre) of agencies is forbidden. The government has some formal levers in relation to the agencies (they are autonomous, not independent): it appoints the agency head, issues yearly "instructions", and provides agencies with an annual budget that can be withdrawn at any time. The government relies on informal dialogues and unofficial suggestions, enhanced by "a strong sense of loyalty towards the government of the day among the civil servants" (Pierre, 2020 , p. 2). Importantly, the Swedish constitution does not allow for exceptions during crises. A national response to a large-scale crisis continues to be run by autonomous agencies. ${ }^{3}$

Swedish crisis management is guided by a simple principle: the actor responsible for a certain policy issue during normal times is also responsible for that issue during a crisis (Becker \& Bynander, 2017, p. 75). The Ministry for Health and Social Affairs and its agencies, the FOHM and

${ }^{3}$ A light degree of coordination does take place from the central government via a standing crisis council-a governance innovation started in 2005 following Sweden's experience in the Asian Tsunami (Becker \& Bynander, 2017). 
National Board for Health and Welfare (NBHW) are thus responsible for managing a pandemic in coordination with related agencies such as the Swedish Civil Contingencies Agency (MSB).

The FOHM's Director-General, Johan Carlson, is responsible for Sweden's coronavirus strategy and gives advice to politicians at all levels (Bendjelloul \& Lindqvist, 2020). Through instructions, the government has authorized the FOHM to issue guidelines for businesses and the public to contain the spread of any virus. It can issue regulations (föreskrifter) with legal sanctions or general advice (allmänna råd) without legal sanctions. Unlike laws, these do not require parliamentary approval. If a law must be changed during a pandemic, for instance to ban public gatherings, the agency issues a request (bemställan) to the government.

Director-general Carlson is supported by chief epidemiologist Anders Tegnell and other civil servants at the FOHM. The chief epidemiologist oversees the monitoring of contagious diseases in Sweden. ${ }^{4}$

The FOHM can convene the National Pandemic Group (NPG) to ensure coordination of the measures aimed at containing the pandemic. ${ }^{5}$ The NPG is an informal structure consisting of representatives from all agencies involved in pandemic preparedness and management (FOHM, 2019). ${ }^{6}$ The aim of the forum is to address potential overlap and to coordinate communication from and amongst the agencies (MSB and Socialstyrelsen, 2011, p. 51).

\subsubsection{The Netherlands: Ministers as Crisis Manager}

In the Netherlands, the Minister of Health, Welfare and Sport (hereafter, Minister of Health) is formally responsible for the management of a pandemic response. The prime minister can oversee crisis response tasks that are not directly related to health questions. This coordination takes place in meetings of the Ministerial group "Crisismanagement," which is chaired by the prime minister (NCTV, 2020).

\footnotetext{
${ }^{4}$ It would thus be more logical to bring forward the Director General than the Tegnell at the press conferences and in media interviews (Olsson, 2020).

${ }^{5}$ During a pandemic, the FOHM collaborates closely with the 21 regional infection control physicians (Smittskyddsläkare). They are in charge of reporting the epidemic development in each region to the FOHM (MSB and Socialstyrelsen, 2011, p. 12).

${ }^{6}$ The agencies represented in NPG are the FOHM, the NBHW, MSB, the Medical Products Agency (MPA), Swedish Work Environment Authority (AV), Swedish Association of Local Authorities and Regions (SKR/SALAR), and the county administrative boards.
} 
The Minister of Health benefits from the advice of experts, who are assembled in the so-called Outbreak Management Team (OMT). The OMT is formally convened by the National Institute for Public Health and Environment (RIVM) but operates independently. OMT members are doctors and researchers with university affiliations. Other experts may be invited to join OMT meetings and discuss topics from the point of view of their respective expertise (Rijksinstitunt voor Volksgezondheid en Milieu [RIVM], 2020). The OMT is headed by Jaap van Dissel, a professor of internal medicine specialized in infectious diseases and head of the Center for Infectious Disease Control (CIb) (RIVM, 2011).

The OMT offers its advice to the Ministry of Health, in which issues are discussed collectively by representatives of local government and other departments (in the so-called $\mathrm{BAO}$ committee). The $\mathrm{BAO}$ considers whether the OMT advice is feasible from a political, societal, and administrative perspective. The BAO [Bestuurlijk afstemmingsoverleg] then advises the Minister of Health (RIVM, n.d.). The implementation of behavioral guidelines is in the hands of the 25 "safety regions" of the Netherlands (NCTV, 2020).

The OMT advice gained considerable stature and publicity during the first phase of the pandemic. Dutch prime minister Rutte often assured the public that he was acting on the basis of scientific advice, at one point saying that the OMT advisories had a "holy" status (Rijksoverheid, 2020d). In reality, the relationship between the OMT experts and the political crisis managers adhered to the crisis "hierarchy": experts offered advice, politicians made the decisions (Boin et al., 2020).

\subsection{Six CRITICAL WeEkS}

The experts did not miss or ignore the information about a new virus emerging in China. By the second week of January, they had the virus firmly on their radar. Experts from both countries were quick to start research on the new coronavirus. In Sweden, experts at the national reference laboratory (Nationellt referenslaboratorium, NRL) for parasitology began diagnosing the virus (FOHM, 2020b). In the Netherlands, the Erasmus Medical Centre started participating in international research in collaboration with the WHO (NOS, 2020b).

Key experts in both countries were remarkably quick to offer statements about the new virus. The first messages from the Swedish experts were positive and confident. On January 16, chief epidemiologist Anders Tegnell stated that for the coronavirus "to become a large outbreak, it is 
required that the virus is good at spreading from human to human. That does not seem to be the case with this virus" (FOHM, 2020c). The chief expert moreover claimed that a new SARS-like epidemic was not likely (Alexandersson, 2020) and that the virus was less dangerous than the former coronaviruses of SARS and MERS (Höglund, 2020).

Experts in the Netherlands offered similar assessments, reminding the public that "there are no direct flights from Wuhan to the Netherlands", "the virus does not appear to be very contagious," and "we have protocols ready" (Nieuwenhuis \& Van Zon, 2020; NOS, 2020a). On January 24, when the first corona case was reported in Europe, RIVM spokesperson Harald Wychgel stated that the risk of infections in the Netherlands was "very low" (Taha, 2020).

Chinese experts had a more alarming message for their international colleagues. In January, they confirmed that the virus was transmitted human-to-human (even though there was still uncertainty about how easily the virus was transmitted). The incubation period was estimated to vary between 3 and 14 days.

The experts of the Dutch Outbreak Management Team acted upon the scientific findings and advised the Minister of Health on January 27 to classify the new coronavirus an "A-disease" (an exclusive list of dangerous diseases such as Ebola, SARS, and Smallpox). The minister did so the same day (Jak, 2020). The Swedish experts issued the same request to their government on January 31. On February 1, the Swedish government classified the coronavirus an A-disease (FOHM, 2020d).

The A-status has legal implications in both countries. In the Netherlands, it places the response firmly in the hands of the Minister of Health, who receives far-reaching powers, and requires doctors and hospitals to report suspected cases (Jak, 2020). In Sweden, the A-disease status triggers the possibility for mandatory contact-tracing and reporting in accordance with the Communicable Disease Act. It gives authorities power to decide on quarantine measures and isolation of contagious individuals (FOHM, 2020d).

Nevertheless, experts still offered rather conservative assessments in public regarding the new and unknown threat faced by the public. Even after the arrival of the virus in Sweden on January 31, the FOHM and the government continued to downplay the risk of the virus spreading in Swedish society. The FOHM did not heighten its risk assessment from "very low" to "low" until three weeks into February (FOHM, 2020a). The government and experts were confident that Sweden was 
well-prepared, even if the virus arrived. The government mimicked the messages sent by the experts. The shared view was that the new virus was not as dangerous as previous coronaviruses (Von Hall, 2020).

On February 1, 2020, the same day that the FOHM asked the WHO to clarify how the new coronavirus was transmitted (Runblom, 2020), the agency tweeted there was no scientific evidence that the virus spreads during the incubation period (Folkhälsomyndigheten, 2020a). The following day, however, the WHO stated that the virus could in fact transmit during the incubation period (the FOHM shared this clarification with the public) (Folkhälsomyndigheten, 2020b). On February 2, Sweden evacuated dozens of citizens from Wuhan, China. The FOHM advised people returning from China to be attentive to symptoms; quarantine was not deemed necessary.

Dutch experts communicated in similar vein. In mid-February 2020, the OMT chairman, Jaap van Dissel, gave his second technical briefing to members of parliament. During the briefing, Van Dissel explained that much about the coronavirus was still unknown. He confidently stated, though, that random testing of people without symptoms would be ineffective (Tweede Kamer der Staten-Generaal, 2020a). On February 21, Aura Timen, a member of the OMT, said that based on the available data, she did not think the virus would spread quickly throughout Europe (KNAW, 2020).

The WHO had classified the coronavirus a public health emergency of international concern as early as January 30 (BBC, 2020). Yet, not much happened in February. Neither of the countries started screening incoming travelers because experts argued it would be ineffective, nor were behavioral modifications suggested (FOHM, 2020c; Rijksoverheid, 2020e). Events like carnivals, professional soccer games, and pop concerts continued unabated.

On February 27, the first coronavirus case was reported in the Netherlands (NU, 2020). The day earlier, a second corona case was spotted in Sweden, almost a month after the first case had been reported (TT, 2020a). Yet experts and politicians in both Sweden and the Netherlands remained calm when they heard the news and stayed confident that they could control the situation. That would soon prove an illusion. The explosion of corona cases in northern Italy occurred during the Spring Break for many European countries. This synchronicity allowed for the virus to spread quickly throughout Europe. 
Indeed, everything changed in March. The number of corona cases started to increase rapidly in both countries. On March 3, the number of cases in Sweden shot up to 79 (Brischetto, 2020). That same day, 23 corona cases were reported in the Netherlands (NOS, 2020c). The first Covid-19 patient died on March 6 in the Netherlands (NU, 2020). The first Covid-19 related death in Sweden occurred on March 11 (TT, 2020a).

On March 6, after receiving alarming messages from hospitals in the Dutch province of Noord-Brabant, Van Dissel said that "this is a wake-up call, a lot is eluding the medical radar" (Hoedeman \& Klaassen, 2020). That weekend, testing of staff in several hospitals in Noord-Brabant showed that $4 \%$ of the medical staff was infected. On March 10, Van Dissel warned parliamentarians that the healthcare system could soon be overwhelmed, and new cases might no longer be traceable (Tweede Kamer der Staten-Generaal, 2020b). Surprisingly, on March 13, Van Dissel reassured people in an interview with the daily newspaper de Volkskrant that it was safe to visit bars and restaurants (Van den Dool, 2020). The bars and restaurants were closed two days later.

In Sweden, on March 10, the FOHM heightened its risk assessment for domestic spread to "very high." The following day, the first corona death was reported and the first measure (a ban on events with more than 500 guests) was put in place (TT, 2020a). On March 12, Swedish authorities quit contact tracing as, according to chief epidemiologist Tegnell, this was "now meaningless" (Expressen TV, 2020). Sweden changed its course and no longer strictly followed the WHO protocols. Rather than attempting a suppression approach, as most European countries did, Sweden opted for a mitigation approach that sought to flatten but not eliminate the curve of infections. ${ }^{7}$

\footnotetext{
${ }^{7}$ Many European countries opted for a suppression approach rather than a mitigation approach after the Imperial College London published Corona Report 9. The mitigation approach aims at slowing down the spread of the virus yet not necessarily stopping it completely. The suppression approach aims at reducing the growth of the virus as much as possible and keeping it at a low level. The report created quite a fuss because it stated that if the UK government were to continue its mitigation approach, hundreds of thousands of people would die because of Covid-19. A challenge of the suppression approach is, however, that it must be maintained until a vaccine is available (Ferguson et al., 2020).
} 


\subsection{Blindsided: Explaining the Slow Response In the NetherLands and Sweden}

In both countries, top health experts repeatedly reassured politicians and the public that everything was under control. Even though much about the virus was unknown, experts suggested that they understood the virus and its mode of propagation. Perhaps most worryingly, they were slow to understand that they had been wrong about the virus for quite some time-thus delaying the response.

How is it possible that top experts, highly qualified and experienced, were slow to recognize an announced pandemic? We offer four possible explanations for the position of these experts, garnered from previous research as well as evidence from this case.

\subsection{1 “It Won't Happen Heve"}

For decades, a global pandemic has featured on virtually every list of possible future crises. The arrival of a new, deadly flu pandemic seemed just a matter of time. In recent years, modern societies have experienced new and deadly diseases (AIDS, SARS, MERS, bird flu). After the SARS outbreak in 2003, the European Center for Disease Prevention and Control (ECDC) was established (and located in Stockholm). The EU continued to develop its Early Warning Systems for health (Guglielmetti, Coulombier, Thinus, Van Loock, \& Schreck, 2006). It is thus no surprise that both Sweden and the Netherlands had experts ready to advise- or in the case of Sweden, to manage - the decision-making process aimed at formulating a pandemic response.

Remarkably, however, the experts did not seem to believe that the coronavirus would wreak havoc in their own country. They learned about the new virus and dutifully began to study it. They agreed that it was a dangerous disease and classified it an A-disease. Nevertheless, they did not appear to accept the reality of a contagious virus crossing borders in a borderless world. A few months into the disaster, several experts in the Netherlands explained how they had underestimated the virus:

We never experienced this before, it is chilling ... When we saw the first data from China, we said to each other: this is weird, this cannot be. The speed of development surprised us ... [We thought:] This looks like a measurement error-Jacco Wallinga, head of the Infectious Disease Modelling unit at the RIVM. (Boin et al., 2020, p. 32) 
I, too, saw the images from China. And I thought "Well, it will not be that bad", and then it reached Italy and then I saw the images again ... You see it, but you do not feel it. Only when you feel it, you are aware of it-Diederik Gommers, Professor Intensive Care Medicine at Erasmus Medical Centre. (Boin et al., 2020, p. 32)

On Friday February 21, I spoke at a symposium in Amsterdam. I had analyzed the situation in Europe: in Italy they had three corona cases, people from China, who had been in the hospital since the end of January. Nothing else. We had two groups of infections in Europe: one in France, one in Germany. So, I said during my speech that the risks were not that high. Later on, I was heavily attacked, I think rightly so; I was perhaps overconfident-Aura Timen, head of the National Coordination Centre for Communicable Disease Control at the RIVM. (Boin et al., 2020, p. 40)

In Sweden, experts were convinced that they knew how to handle a pandemic. Sweden would impose measures in a step-wise, incremental fashion in order to learn from experience which measures had the best effects. The experts soon found out that it was harder than they had envisioned. Chief epidemiologist Tegnell admitted on March 8 that he initially thought China would contain the virus and that it would not spread outside of China (Nordström, 2020). About one month into the crisis, Tegnell stated that his agency should have understood that the death rate was going to be higher than anticipated (Torkelsson, 2020). In June, Tegnell turned self-critical and proclaimed "If we would encounter the same disease, with the knowledge that we have about it today, I think we would end up doing something between what Sweden did and what the rest of the world did" (Öhman \& Rosén, 2020).

A few months into the pandemic, experts who had previously supported the Swedish strategy in the face of early criticism, turned critical themselves:

If we were to do this again, I think we would have imposed tougher measures in the beginning. We should have known that we lacked sufficient preparedness in our health and elderly care. A lockdown would have given us the chance to prepare, think things through, and curb the spread of infection to a maximum. But even with the benefit of hindsight, I don't know if I would have been wiser than our leadership was.

-Annika Linde, former chief epidemiologist of Sweden (Svahn, 2020)

What surprised me the most was how fast everything went. From individual cases to societal spread, from intensive contact tracing to another strategy 
and then back to intensive contact tracing. If you look back, everything went really fast.-Maria Löfgren, infection control physician of Region Halland. (Trysell, 2020)

What surprised me the most was the initial development after the first reports from China on January 1, and the speed to which the contagion spread globally.-Per Follin, infection control physician of Region Stockholm. (Trysell, 2020)

\subsection{2 "Just Following the Science"}

During the early stages of Covid-19, experts in both Sweden and the Netherlands closely adhered to the paradigm and protocols of the WHO on the management of a pandemic. The protocols were quite limited in nature and had shaky foundations. The available scientific literature at the time offered little evidence upon which to base WHO prescriptions (Aledort, Lurie, Wasserman, \& Bozette, 2007; WHO Writing Group, 2006). The WHO prescribed a set of simple behavioral guidelines that were thought to be sufficient for an effective pandemic response. These guidelines pertained to personal hygiene and social distancing in combination with the isolation of infected people ("stay home if you have symptoms").

Swedish and Dutch experts followed the WHO guidelines and advised accordingly. They repeatedly emphasized the importance of washing hands and sneezing in elbows. The next step - not shaking hands-was the epitome of governmental intervention, the highest ladder on the escalation ladder (according to WHO wisdom at the time).

Another WHO prescription was to test patients and trace the contacts of people who had contracted the virus, in order to map the spread of the virus and identify new patients. Once the identification of patients and tracing their contacts was no longer possible, and the virus could no longer be contained, the WHO prescribed that so-called non-pharmaceutical interventions (NPIs) should be considered. On March 7, the WHO recommended measures to avoid crowding and mass gatherings. It suggested that countries had to "define rationale and criteria for use of social distancing measures such as (...) school closure" (WHO, 2020b, p. 2).

In the literature, as experts surely knew, there was little evidence for the effectiveness of social distancing, closing shops, schools, and restaurants. There was also little evidence suggesting that large-scale events should be 
canceled (WHO Writing Group, 2006). In fact, in the words of the WHO (2006, p. 9), even "the effectiveness of personal hygiene is plausible but not evidence-based."

This placed experts in a quandary. Should they stick with the science or follow unproven guidelines? In Sweden, the FOHM issued a request to the Swedish government to prohibit public gatherings on March 11. Swedish experts did not support the idea of school closure. But the government did not want to completely forego this policy option, should the experts change their mind. For that purpose, on March 19, the Parliament passed a new bill that empowered the government to temporarily close schools. Experts maintained there was no scientific evidence to support the idea that closing schools would reduce the risk of infection spread (FOHM, 2020e). All schools, except upper secondary schools and universities, stayed open. Sweden stuck with an approach founded on evidencebased knowledge.

On March 12, Dutch Prime Minister Rutte announced the first measures. People were recommended to work from home as much as possible, universities and colleges were told to provide online classes, and events of more than 100 guests were prohibited (Rijksoverheid, 2020b). On March 15 , it was announced that bars, restaurants, gyms, sports clubs and schools had to close (Rijksoverheid, 2020c). On March 23, all events were canceled, social gatherings were only allowed with a maximum of three people while adhering to social distancing rules, and contact professions (hairdressers, nail salons, etc.) were told to close (Rijksoverheid, 2020f). Some of these measures (closing schools, bars, and restaurants) were not recommended by the OMT scientists. The political crisis managers, however, overrode their advisors.

\subsection{3 “The Public Won't Adbere to Extreme Measures"}

Crisis managers sometimes base their decisions on misinformed beliefs. One persistent belief, for instance, is that the public will panic if it learns about the extent and potential impact of an impending threat. Another one is the assumption that people in a disaster setting will riot and loot. ${ }^{8}$ International experts seemed to believe that non-pharmaceutical interventions (social distancing, school closures, etc.) were "likely to be ineffective,

\footnotetext{
${ }^{8}$ There is extensive evidence showing that these beliefs are not true (see, for instance, Quarantelli, 1988).
} 
infeasible or unacceptable to the public" (Aledort et al., 2007, p. 208). As we now know, there is no truth to that belief (people and businesses everywhere voluntarily adhered to strict lockdown regimes).

In the early phase of the emerging threat, Dutch experts were convinced that far-reaching measures might reach too far. For instance, the experts did not consider the termination of "carnaval" festivities-a traditional event in the southern Dutch provinces, which subsequently suffered terribly from the first onslaught of the virus. Van Dissel later explained that "he would not have been able to sell it" if he had proposed to cancel the festivities (Hoedeman \& Klaassen, 2020). The OMT experts would experience more difficulties in "reading" the public mood, prompting the creation of a behavioral assessment unit to meet this challenge.

Sweden adhered to the notion that extreme, long-term measures might be ineffective, if not counterproductive. The FOHM settled on less extreme restrictions, designed in such a way that they could be followed by the public for an extended period, since the agency argued that "the virus will remain in society for a long time" (FOHM, n.d.). The Swedish strategy left much discretion to individual Swedes. Sweden thus followed the responsibility principle whereby authorities trust the public to adhere to their general advice. Similarly, the public trusts the authorities and displays a high degree of voluntary compliance. Nonetheless, when people did not follow the governmental recommendations, the authorities did not hesitate to toughen the measures. In some cases, the recommendations became laws (for instance, the national visit ban on nursing homes). The government also threatened to close restaurants if they did not follow the regulations imposed on them (Malm, 2020). These were adopted, however, quite late after the onset of the pandemic.

\subsection{4 "We Are Well Prepared"}

In the absence of a vaccine, preparedness had to rely on strong organization. An effective response, from this perspective, is based on the identification of the "index patient" - the first known patient in a country. Through tracking the contacts of the index patient, other infected people can be "chased down" and placed in quarantine. This tracking and tracing of suspected cases is no rocket science, but it requires substantial resources, well-trained personnel, and excellent managerial skills.

On paper, both countries were well prepared to perform this task. The Dutch had plans and organizational units in place. In 2005, the Center for 
Infectious Disease Control (CIb) was created. This center was established to enhance the preparedness of the country in the face of the rising threat of new infectious diseases (RIVM, 2015). Over the years, Dutch preparedness was tested by the emergence of various new diseases. The available plans and organizational structure performed well in response to these health threats. The SARS and Mexican Flu outbreaks, for example, were detected early on and the situation was quickly brought under control (Boin et al., 2020). These successes inspired deep confidence amongst Dutch experts and politicians in their state of preparedness.

Unfortunately, this pandemic was different. Due to the long incubation time and the many asymptomatic cases, there were many index patients (until the first index patient was finally identified). ${ }^{9}$ In addition, the capacity for testing suspected cases was limited. When the first corona case was reported in the Netherlands, the OMT stated that the best thing to do was to contain the virus by actively tracing patients and their contacts (Rijksoverheid, 2020g). However, the responsible organizational unitsthe local health units-were not prepared for the task. On March 10, the head of one of the local health units said that her employees were very busy and that "the work pressure is sky high" (Tweede Kamer der StatenGeneraal, 2020b). On March 12, Van Dissel told the press that it was impossible to trace all new corona cases. The Dutch government gave up on mass testing and contact tracing (Rijksoverheid, 2020b).

The Swedes also had plans and organizational units in place to handle imported cases and to perform contact tracing. The Swedish authorities began conducting active contact tracing after the first case was discovered on January 31 . For almost a month, the number of corona cases reported in Sweden remained in single digits. On February 26, when Gothenburg experienced its first case, Anders Tegnell claimed that "our current strategy works - to inform people who have been in the affected areas who get symptoms and to offer them quick treatment" (FOHM, 2020f). By March 12 , however, the number of cases had reached such high levels that Tegnell admitted that contract tracing was impossible and said people in the region of Stockholm were no longer going to be tested (Expressen TV, 2020). Sweden's testing capacity proved to be insufficient. On March 22, the FOHM announced that it no longer considered testing other than in hospitals (Fall, Kämpe, Fall, Larsson, \& Bergh, 2020).

\footnotetext{
${ }^{9}$ According to the RIVM, the first (unofficial) corona cases were already in the Netherlands in January (Algemeen Dagblad, 2020).
} 


\subsection{Recognizing When a Creeping Crisis Comes TO A HeAd: Lessons From Covid-19}

As seen in the case of Covid-19, the move from watching an unfolding crisis to preparing for its onslaught is mediated by the expert-politician interface. That interface can shape how societies prepare for impending crises, from the moment those crises begin to "creep."

The world of science is ruled by methods of validation, which aim to separate mere beliefs from societal patterns and laws of nature. The political arena revolves around value conflicts that must be abridged through negotiation and mechanisms of delegating and monitoring power. Politicians often ask scientists for advice, which they use as they see fit. Scientists bemoan that policy is not evidence based, but they rarely refrain from offering their insights when asked.

When in crisis, politicians tend to pay more attention to what scientists have to say. Suddenly they want to know what the basis is for their scientific insights. Scientists are hard pressed to provide advice on which much may depend. They move into positions that are as close to decision-making power as non-elected officials may find themselves. The Covid-19 crisis was no exception. In the Netherlands, as in other countries, scientists who had labored anonymously for years suddenly shared the stage with political crisis managers. In Sweden, scientists pretty much ran the response, placing politicians in the back benches of the crisis management arena.

So, what have we learned? Did the relationship between scientists and decision-makers help the latter to declare this creeping crisis a full-blown crisis, in good time? Should the relationship between policymakers and scientists be reconsidered?

To start, scientists clearly did not call Covid-19 for what it was: one of the biggest crises to hit the world since World War II. Experts followed the science, which, in hindsight, helps to understand why it took so long to declare this a full crisis. Well into the crisis, scientists "missed" the emerging crisis in the nursing homes (a creeping crisis within a creeping crisis). As we write this, in late 2020, it appears that scientists failed to call the "second wave"-a resurgence of Covid-19. These observations are, of course, disconcerting.

We identified an interesting divergence between the two countries. In the Netherlands, politicians closely followed the assessments of scientists during the incubation phase. But when it became abundantly clear that the experts had misread the threat, the politicians took over. Belatedly but 
swiftly, they took measures that experts had waved off as not supported by scientific evidence.

In Sweden, science remained in the driving seat. Swedish scientists stuck with the evidence-based regime that their Dutch colleagues had prescribed to their political headmasters. Put differently, Swedish politicians remained true to the designed crisis management principles and practices. The Swedish approach, as it subsequently came to be known, attracted world-wide attention. It was nothing but the regime that scientists had proposed in international journals and had agreed upon during international conferences. Remarkably, Sweden was the only country that stuck with science (Milne, 2020). Whether the Swedes were right to do so will be the subject of much future research (it will take some time before the final assessment comes in). Sweden has become a test lab for pandemic management; that much is clear.

It also seems clear that the advisory role of scientists should not be abandoned. It is hard to see how a pandemic could be managed without the insights of science. But our analysis of two countries in which scientists play a major role in pandemic management offers a few pointers for further discussion and analysis. These points are relevant in all creeping crises. Three points in particular merit attention:

Scientists advise, politicians decide-or not? The role of scientists seems circumscribed in modern conceptions of democracy. While scientists may have critical knowledge and insights regarding strategy and decisions, democracies expect politicians to make those decisions. They are elected and they are responsible. Is there reason to reconsider this maxim? Scientists should stick with the science. The scientists disappointed in the initial phase of the Covid-19 crisis. They did so because they stuck with the scientific paradigm. It seems logical that scientists should stick with the science. If the science is limited, so be it. Scientists should admit ignorance and hand the decision back to politicians. They may start working to address the uncertainty by conducting research.

Who should declare a crisis? The calling of the pandemic was in the hands of politicians, but they did so based on scientific assessments. Politicians dutifully categorized Covid-19 an A-disease when scientists advised them to do so. But scientists failed to persuade politicians of the urgency of the threat and the need to act. The reason is simple: they did not believe it was necessary. This evokes the question: who should declare a crisis and based on what evidence? 


\section{REFERENCES}

Aledort, J., Lurie, N., Wasserman, J., \& Bozette, S. A. (2007). Non-pharmaceutical public health interventions for pandemic influenza: An evaluation of the evidence base. BMC Public Health, 7(208), 1-9. https://doi.org/10.1186/14712458-7-208

Alexandersson, M. (2020, January 16). Epidemiolog: "Ny sarsepidemi osannolik". Svenska Dagbladet. Retrieved November 19, 2020, from https://www. svd.se/epidemiolog-ny-sarsepidemi-osannolik

Algemeen Dagblad. (2020, June 4). Corona was al in januari in Nederland. Algemeen Dagblad. Retrieved November 19, 2020, from https://www.ad.nl/ binnenland/corona-was-al-in-januari-in-nederland a 27ef0fb /

BBC. (2020, January 31). Coronavirus declared global health emergency by WHO. BBC. Retrieved November 19, 2020, from https://www.bbc.com/ news/world-51318246

Becker, P., \& Bynander, F. (2017). Chapter 4: The system for crisis management in Sweden: Collaborative, conformist, contradictory. In C. N. Madu \& C.-H. Kuei (Eds.), Handbook of disaster risk reduction \& management (pp. 69-95). New Jersey: World Scientific Press \& Imperial College Press. https://doi.org/10.1142/9789813207950_0004

Bendjelloul, J., \& Lindqvist, J. (2020, April 5). Folkhälsomyndighetens Johan Carlson: Det är klart att det kan kännas lite skrämmande. Dagens Nyheter. Retrieved November 19, 2020, from https://www.dn.se/nyheter/sverige/ folkhalsomyndighetens-johan-carlson-det-ar-klart-att-det-kan-kannas-liteskrammande/

Boin, A., Overdijk, W., Van der Ham, C., Hendriks, J., \& Sloof, D. (2020). Covid-19: Een analyse van de nationale crisisrespons. Leiden: The Crisis University Press.

Brischetto, L. (2020, March 3). Inga reserestriktioner till Italien-trots stigande dödstal. SVT Nyheter. Retrieved November 19, 2020, from https://www.svt. se/nyheter/inga-reserestriktioner-till-italien-trots-stigande-dodstal

Buckley, C., \& Myers, S. L. (2020, February 1). As new Coronavirus spread, China's old habits delayed fight. The New York Times. Retrieved November 19, 2020, from https://www.nytimes.com/2020/02/01/world/asia/chinacoronavirus.html.

DN-TT. (2020, March 25). Forskare i upprop till regeringen. Dagens Nyheter. Retrieved November 19, 2020, from https://www.dn.se/nyheter/sverige/ forskare-i-upprop-till-regeringen/

ECDC [European Centre for Disease Prevention and Control]. (2020, February 13). Risk assessment: Outbreak of severe acute respiratory syndrome coronavirus 2 (SARS-CoV-2): increased transmission beyond China-fourth update. Retrieved November 19, 2020, from https://www.ecdc.europa.eu/en/publicationsdata/outbreak-severe-acute-respiratory-syndrome-coronavirus-2sars-cov-2-increased 
Expressen TV. (2020, March 12). Statsepidemiologen Anders Tegnell: 'Meningslöst med smittspårning nu' [Interview]. Expressen TV. Retrieved November 19, 2020, from https://www.expressen.se/tv/nyheter/coronaviruset/statsepidemiologen-anders-tegnell-meningslost-med-smittsparning-nu/

Fall, T., Kämpe, O., Fall, K., Larsson, N-G., \& J. Bergh. (2020, March 22). DN Debatt: Akut att Sverige testar fler-forskningslabb kan hjälpa till. Dagens Nyheter. Retrieved November 19, 2020, from https://www.dn.se/debatt/ akut-att-sverige-testar-fler-forskningslabb-kan-hjalpa-till/

Ferguson, N., Laydon, D., Nedjati-Gilani, G., Imai, N., Ainslie, K., Baguelin, M., ... Ghani, A. (2020). Report 9: Impact of non-pharmaceutical interventions (NPIs) to reduce Covid-19 mortality and healthcare demand. Imperial College London, 10, 77482. https://doi.org/10.25561/77482

FOHM [Folkhälsomyndigheten]. (2019). Pandemiberedskap. Hur vi förbereder oss-ett kunskapsunderlag. Folk 19074-1. Retrieved from https://www. folkhalsomyndigheten.se/contentassets/b6cce03c4d0e4e7ca3c984l bd96e6b3a/pandemiberedskap-hur-vi-forbereder-oss-19074-1.pdf

FOHM [Folkhälsomyndigheten]. (2020a, March 6). Pressträff om den nationella pandemigruppens möte. Retrieved November 19, 2020, from https://www. folkhalsomyndigheten.se/nyheter-och-press/nyhetsarkiv/2020/mars / presstraff-om-den-nationella-pandemigruppens-mote/

FOHM [Folkhälsomyndigheten]. (2020b, February 13). Utökad kapacitet för diagnostik av det nya coronaviruset. Retrieved November 19, 2020, from https://www.folkhalsomyndigheten.se/nyheter-och-press/nyhetsarkiv/2020/ februari/utokad-kapacitet-for-diagnostik-av-det-nya-coronaviruset/

FOHM [Folkhälsomyndigheten]. (2020c, January 16). Nytt coronavirus upptäckt i Kina. Retrieved November 19, 2020, from https://www.folkhalsomyndigheten.se/nyheter-och-press/nyhetsarkiv/2020/januari/nyttcoronavirus-upptackt-i-kina/

FOHM [Folkhälsomyndigheten]. (2020d, January 31). Folkhälsomyndigheten föreslår att nytt coronavirus tas upp i smittskyddslagen. Retrieved November 19, 2020, from https://www.folkhalsomyndigheten.se/nyheter-och-press/ nyhetsarkiv/2020/januari/folkhalsomyndigheten-foreslar-att-nyttcoronavirus-tas-upp-i-smittskyddslagen/

FOHM [Folkhälsomyndigheten]. (2020e, March 1). Ingen effektiv åtgärd att låta friska skolbarn stanna hemma. Retrieved November 19, 2020, from https:// www.folkhalsomyndigheten.se/nyheter-och-press/nyhetsarkiv/2020/mars/ avstangning-av-friska-skolbarn-ingen-effektiv-atgard/

FOHM [Folkhälsomyndigheten]. (2020f, February 26). Nytt bekräftat fall av covid-19. Retrieved November 19, 2020, from https://www.folkhalsomyndigheten.se/nyheter-och-press/nyhetsarkiv/2020/februari/ nytt-bekraftat-fall-av-covid-19/ 
FOHM [Folkhälsomyndigheten]. (n.d.). Folkhälsomyndighetens arbete med covid-19. Retrieved November 19, 2020, from https://www.folkhalsomyndigheten.se/smittskydd-beredskap/utbrott/aktuella-utbrott/covid-19/ folkhalsomyndighetens-arbete-med-covid-19/

Folkhälsomyndigheten [@Folkhalsomynd] (2020a, February 1). Vi får många frågor om coronaviruset smittar under inkubationstiden. Vàr bedömning är att det smittar när patenten är sjuk och vid insjuknandet. De källor som bävdar att det skulle smitta under inkubationstiden saknar vetenskapligt stöd. Läs mer $i$ vàr FAQ [Tweet]. Twitter. Retrieved from https://twitter.com/Folkhalsomynd/ status/1223587292759101441

Folkhälsomyndigheten [@Folkhalsomynd] (2020b, February 2). WHO klargör: Sällsynt att symtomfri smittar vidare det nya coronaviruset. Det smittar när patienten är sjuk och $i$ samband med insjuknandet. Läs våra frågor och svar [Tweet]. Twitter. Retrieved from https://twitter.com/Folkhalsomynd/ status/1223888824411074560

Guglielmetti, P., Coulombier, D., Thinus, G., Van Loock, F., \& Schreck, S. (2006). The early warning and response system for communicable disease in the EU: An overview from 1999 to 2005. Eurosurveillance, 11(12). https://doi. org/10.2807/esm.11.12.00666-en

Hoedeman, J., \& Klaassen, N. (2020, May 2). 'Dat kutvirus', verzuchtte de premier. Reconstructie van een wanhopige strijd. Het Parool. Retrieved November 19, 2020, from https://www.parool.nl/nieuws/dat-kutvirus-verzuchtte-depremier-reconstructie-van-een-wanhopige-strijd b $46 \mathrm{c} 25 \mathrm{ec} /$

Höglund, J. (2020, January 16). Nytt lungvirus spritt till Japan—höjd beredskap även i Sverige. Göteborgs-Posten. Retrieved November 19, 2020, from https:// www.gp.se/nyheter/världen/nytt-lungvirus-spritt-till-japan-höjdberedskap-även-i-sverige-1.22694993

Jak, T. (2020, January 28). Wuhan-virus is in Nederland nu een A-ziekte, maar een besmetting is hier nog niet geconstateerd. Trouw. Retrieved November 19, 2020, from https://www.trouw.nl/nieuws/wuhan-virus-is-in-nederland-nueen-a-ziekte-maar-een-besmetting-is-hier-nog-niet-geconstateerd b7c2d78c/

Kester, J. (2020, March 17). Groot vertrouwen in Rutte én zijn aanpak van het coronavirus na toespraak. EenVandaag. Retrieved November 19, 2020, from https://eenvandaag.avrotros.nl/panels/opiniepanel/alle-uitslagen/item/ groot-vertrouwen-in-rutte-en-zijn-aanpak-van-het-coronavirus-na-toespraak/

KNAW [De KNAW]. (2020, May 19). KNAW webinar: het nieuwe coronavirus [video]. YouTube. Retrieved November 19, 2020, from https://www.youtube.com/watch?v=o5fhT0NVfe 4

Lawler, D. (2020, March 24). Timeline: How Italy's coronavirus crisis became the world's deadliest. Axios. Retrieved November 19, 2020, from https://www. axios.com/italy-coronavirus-timeline-lockdown-deaths-cases-2adb0fc7-6ab54b7c-9a55-bc6897494dc6.html 
Lönegård, C. (2020, February 28). M-ledarens kritik: "Känns förvirrande". Svenska Dagbladet. Retrieved November 19, 2020, from https://www.svd. se/m-ledarens-coronakritik-historia-av-att-reagera-sent

Malm, S. (2020, April 24). Hotet mot krögarna—när tillsynen ökar. Expressen. Retrieved November 19, 2020, from https://www.expressen.se/nyheter/ coronaviruset/just-nu-presstraff-med-damberg-om-coronaviruset/

Milne, R. (2020, October 16). Sweden's solitary voice in a crisis. Financial Times, p. 17.

MSB \& Socialstyrelsen. (2011). Influensa A (HIN1) 2009: utvärdering av förberedelser och hantering av pandemin. Retrieved from https://www-edit.msb.se/ siteassets/dokument/om-msb/vart-uppdrag/regeringsuppdrag/2011/ 110201-hantering-av-pandemin-2009.pdf

NCTV. (2020, March 9). Nationale crisisstructuur actief voor coronavirus. Retrieved November 19, 2020, from https://www.nctv.nl/actueel/ nieuws $/ 2020 / 03 / 09 /$ nationale-crisisstructuur-actief-voor-coronavirus

Nieuwenhuis, M., \& Van Zon, H. (2020, January 18). RIVM 'alert op' mysterieus Chinees virus: 'mogelijk 1700 besmettingen'. Algemeen Dagblad. Retrieved November 19, 2020, from https://www.ad.nl/buitenland/rivm-alert-opmysterieus-chinees-virus-mogelijk-1700-besmettingen ae309bc6/

Nordström, I. (2020, March 7). Tegnell medger miss i virus-bedömning: "Trodde att Kina skulle få stopp på det”. Omni. Retrieved November 19, 2020, from https://omni.se/tegnell-medger-miss-i-virusbedomning-trodde-att-kinaskulle-fa-stopp-pa-det/a/pLkM9E

NOS. (2020a, January 22). China meldt ruim 400 besmettingen met coronavirus, negen doden. NOS. Retrieved November 19, 2020, from https://nos.nl/ artikel/2319660-china-meldt-ruim-400-besmettingen-met-coronavirusnegen-doden.html

NOS. (2020b, January 17). Chinese coronavirus niet in Europa, maar Erasmus MC is er toch druk mee. NOS. Retrieved November 19, 2020, from https:// nos.nl/artikel/2318973-chinese-coronavirus-niet-in-europa-maar-erasmusmc-is-er-toch-druk-mee.html

NOS. (2020c, March 3). Corona-overzicht: weer nieuwe besmettingen, 'reis liever niet naar Noord-Italië'. NOS. Retrieved November 19, 2020, from https:// nos.nl/artikel/2325692-corona-overzicht-weer-nieuwe-besmettingen-reisliever-niet-naar-noord-italie.html

Novus. (2020, April 20). Coronastatus 0420 [graphic data]. Novus. Retrieved from https://novus.se/coronastatus-0420-2/

NU.nl (2020, March 27). Tijdlijn: Het coronavirus in Nederland. NU.nl Retrieved from https://www.nu.nl/coronavirus/6040831/tijdlijn-het-coronavirus-innederland.html

Öhman, D., \& Rosén, E. (2020, June 3). Tegnell: Fler åtgärder hade behövts. Sveriges Radio. Retrieved November 19, 2020, from https://sverigesradio.se/ sida/artikel.aspx?artikel $=7487188 \&$ programid $=83$ 
Olsson, S. (2020, April 9). Olsson: Statsepidemiologen lyder under generaldirektören. Nya Wermlands-Tidningen. Retrieved November 19, 2020, from https://www.nwt.se/2020/04/09/olsson-statsepidemiologenlyder-under-generaldirektoren/

Oscarsson, M. (2020, March 19). KD: Statens hantering av corona måste granskas. Expressen. Retrieved November 19, 2020, from https://www.expressen. se/debatt/kd-statens-hantering-av-corona-maste-granskas/

Pierre, J. (2020). Nudges against pandemics: Sweden's Covid-19 containment strategy in perspective. Policy and Society, 39(3), 478-493. https://doi.org/1 $0.1080 / 14494035.2020 .1783787$

Quarantelli, E. L. (1988). Disaster crisis management: A summary of research findings. Journal of Management Studies, 25(4), 373-385. https://doi. org/10.1111/j.1467-6486.1988.tb00043.x

Rijksoverheid. (2020a, March 9). Letterlijke tekst persconferentie minister-president Mark Rutte en directeur Jaap van Dissel (Centrum Infectieziektebestrijding) na afloop van crisisberaad kabinet [Speech]. Retrieved November 19, 2020, from https://www.rijksoverheid.nl/onderwerpen/coronavirus-covid-19/documenten/mediateksten/2020/03/09/letterlijke-tekst-persconferentieminister-president-mark-rutte-en-directeur-jaap-van-dissel-rivm-na-afloopvan-crisisberaad-kabinet

Rijksoverheid. (2020b, March 12). Nieuwe maatregelen tegen verspreiding coronavirus in Nederland. Retrieved November 19, 2020, from https://www. rijksoverheid.nl/actueel/nieuws/2020/03/12/nieuwe-maatregelen-tegenverspreiding-coronavirus-in-nederland

Rijksoverheid. (2020c, March 15). Letterlijke tekst persconferentie ministers Bruins en Slob over aanvullende maatregelen coronavirus [Statement]. Retrieved November 19, 2020, from https://www.rijksoverheid.nl/documenten/mediateksten $/ 2020 / 03 / 15 /$ persconferentie-minister-bruins-en-slob-overaanvullende-maatregelen-coronavirus

Rijksoverheid. (2020d, April 7). Letterlijke tekst persconferentie minister-president Rutte en minister De Jonge na afloop van crisisberaad kabinet (17-4-2020) [Statement]. Retrieved November 19, 2020, from https://www.rijksoverheid. nl/documenten/mediateksten/2020/04/07/letterlijketekst-persconferentie-minister-president-rutte-en-minister-de-jonge-naafloop-van-crisisberaad-kabinet

Rijksoverheid. (2020e, January 27). Advies situatie rondom de uitbraak met het nieuwe coronavirus vanuit Wuban [Letter]. Retrieved November 19, 2020, from https://www.rijksoverheid.nl/documenten/brieven/2020/01/27/ advies-nav-omt-2019-ncov-wuhan

Rijksoverheid. (2020f, March 24). Aanvullende maatregelen 23 maart. Retrieved November 19, 2020, from https://www.rijksoverheid.nl/actueel/ nieuws /2020/03/24/aanvullende-maatregelen-23-maart 
Rijksoverheid. (2020g, February 28). Brief over advies van Outbreak Management Team over Covid-19 [Letter]. Retrieved November 19, 2020, from https:// www.rijksoverheid.nl/documenten/brieven/2020/02/28/briefover-advies-van-outbreak-management-team-over-covid-19

RIVM [Rijksinstituut voor Volksgezondheid en Milieu]. (2011, September 21). Prof. J.T. (Jaap) van Dissel. Retrieved September 14, 2020, from https:// www.rivm.nl/en/about-rivm/knowledge-and-expertise/experts-andexpertise/prof-j-t-jaap-van-dissel

RIVM [Rijksinstituut voor Volksgezondheid en Milieu]. (2015, June 11). Centrum voor Infectieziektebestrijding bestaat 10 jaar. Retrieved September 14, 2020, from https://www.rivm.nl/nieuws/centrum-voorinfectieziektebestrijding-bestaat-10-jaar

RIVM [Rijksinstituut voor Volksgezondheid en Milieu]. (2020, September 2). Outbreak Management Team (OMT). Retrieved September 14, 2020, from https://www.rivm.nl/coronavirus-covid-19/omt\#: :text=De\%20vaste\%20 OMT\%2 Dleden\%2 0zijn,Microbiologie\%20(NVMM)\%20en\%20het\%20 Landelijk

RIVM [Rijksinstituut voor Volksgezondheid en Milieu]. (n.d.). Folder landelijke advisering bij infectieziektedreigingen en -crisis. Retrieved September 14, 2020, from https://www.rivm.nl/folder-landelijke-advisering-bij-infectieziekt edreigingen-en-crises

Runblom, K. (2020, February 1). Uppmaningen till WHO: Förtydliga hur viruset smittar. Sveriges Radio. Retrieved November 19, 2020, from https://sverigesradio.se/sida/artikel.aspx?programid $=83 \&$ artikel $=7399273$

Rutten, R. (2020, April 1). Wilders en Baudet steunen het kabinet met tegenzin. NRC Handelsblad. Retrieved November 19, 2020, from https://www.nrc.nl/ nieuws $/ 2020 / 04 / 01 /$ wilders-en-baudet-steunen-het-kabinet-mettegenzin-a3995648

Spiteri, G., Fielding, J., Diercke, M., Campese, C., Enouf, V. Gaymard, A. ... Ciancio, B.C. (2020). First cases of coronavirus disease 2019 (Covid-19) in the WHO European Region, 24 January to 21 February 2020. Eurosurveillance, 25(9). https://doi.org/10.2807/1560-7917.ES.2020.25.9.2000178

Svahn, C. (2020, May 19). Annika Linde: En månads stängning hade gett oss tid. Dagens Nyheter. Retrieved November 19, 2020, from https://www.dn.se/ nyheter/sverige/annika-linde-en-manads-stangning-hade-gett-oss-tid/

Taha, N. (2020, January 24). Dit doet Nederland als het coronavirus hier opduikt. Algemeen Dagblad. Retrieved November 19, 2020, from https://www.ad.nl/ binnenland/dit-doet-nederland-als-het-coronavirus-hier-opduikt aab5d822/

Torkelsson, A-C. (2020, April 24). Folkhälsomyndigheten har underskattat dödssiffrorna. Omni. Retrieved November 19, 2020, from https://omni.se/ folkhalsomyndigheten-har-underskattat-dodssiffrorna/a/4qe56E 
Trysell, K. (2020, September 9). 21 smittskyddsläkare om coronapandemin. Läkartidningen. Retrieved November 19, 2020, from https://lakartidningen. se/aktuellt/nyheter/2020/09/21-smittskyddslakare-om-coronapandemin/

TT. (2020a, April 5). Detta har hänt: Sverige under coronakrisen-Dag för dag. Dagens Industri. Retrieved November 19, 2020, from https://www.di.se/ nyheter/detta-har-hant-sverige-under-coronakrisen-dag-for-dag/

TT. (2020b, January 31). Smittade kvinnan isolerade sig i hemmet. Aftonbladet. Retrieved November 19, 2020, from https://www.aftonbladet.se/nyheter/a/ BRBKAe/smittade-kvinnan-isolerade-sig-i-hemmet

Tweede Kamer der Staten-Generaal. (2020a). Verslag van een technische briefing, gehouden op 20 februari 2020, over ontwikkelingen Coronavirus. Retrieved November 19, 2020, from https://www.tweedekamer.nl/debat_en_vergadering/commissievergaderingen/details? id =2020A00836

Tweede Kamer der Staten-Generaal. (2020b). Verslag van een technische briefing, gehouden op 10 maart 2020, over ontwikkelingen coronavirus. Retrieved November 19, 2020, from https://www.tweedekamer.nl/debat_en_vergadering/commissievergaderingen/details?id=2020A01119

Van den Dool, P. (2020, March 13). RIVM-baas: 'Helft Nederlanders zal uiteindelijk virus krijgen'. NRC Handelsblad. Retrieved November 19, 2020, from https://www.nrc.nl/nieuws/2020/03/13/rivm-baas-helft-nederlanderszal-uiteindelijk-virus-krijgen-a3993743

Von Hall, G. (2020, January 23). Experten: "Flera tusen kan dö-vaccin utvecklas". Svenska Dagbladet. Retrieved November 19, 2020, from https://www. svd.se/virusexpert-flera-tusen-kan-do\%2D\%2Dvaccin-utvecklas

WHO [World Health Organization]. (2006). Pandemic influenza preparedness planning: Report on the second joint WHO/European Commission workshop, Copenhagen, 24-26 October 2005. Retrieved November 19, 2020, from https://www.euro.who.int/document/e88206.pdf

WHO [World Health Organization]. (2020a). Report of the WHO-China Joint Mission on Coronavirus Disease 2019 (Covid-19). Retrieved November 19, 2020, from https://www.who.int/publications-detail/report-of-the-whochina-joint-mission-on-coronavirus-disease-2019-(covid-19)

WHO [World Health Organization]. (2020b, March 7). Responding to community spread of Covid-19. Interim Guidance. Retrieved November 19, 2020, from https://apps.who.int/iris/bitstream/handle/10665/331421/WHOCovid-19-Community_Transmission-2020.1-eng.pdf? sequence $=1$ \&isAllowed $=\mathrm{y}$

World Health Organization Writing Group. (2006). Nonpharmaceutical interventions for pandemic influenza, international measures. Emerging Infectious Diseases, 12(1), 81-87. https://doi.org/10.3201/eidl201.051370 
Open Access This chapter is licensed under the terms of the Creative Commons Attribution 4.0 International License (http://creativecommons.org/licenses/ by $/ 4.0 /$ ), which permits use, sharing, adaptation, distribution and reproduction in any medium or format, as long as you give appropriate credit to the original author(s) and the source, provide a link to the Creative Commons licence and indicate if changes were made.

The images or other third party material in this chapter are included in the chapter's Creative Commons licence, unless indicated otherwise in a credit line to the material. If material is not included in the chapter's Creative Commons licence and your intended use is not permitted by statutory regulation or exceeds the permitted use, you will need to obtain permission directly from the copyright holder. 